\title{
PENDEKATAN KUALITAS PRODUK UNTUK MENINGKATKAN PEMBELIAN SEPEDA MOTOR YAMAHA N-MAX DI KOTA BOGOR
}

\author{
PRODUCT QUALITY APPROACH TO IMPROVE PURCHASE OF YAMAHA N-MAX \\ MOTORCYCLE IN BOGOR CITY
}

\author{
Endang Silaningsih $^{1)}$; Titiek Tjahja Andari ${ }^{2)}$; Dedeh Widarsih ${ }^{3)}$ \\ Program Studi Manajemen Fakultas Ekonomi Universitas Djuanda Bogor \\ e_mail: silaningsih.toegino@gmail.com; titiektjahja@gmail.com; dedehwidarsi@gmail.com
}

\begin{abstract}
Purchasing decision is the basis for consumers to buy goods or services from many choices of goods or services available. This research was conducted with the aim to determine the effect of product quality (performance, features, reliability, suitability, durability, servicability, aesthetics, and quality impression) of Yamaha N-Max motorcycle on consumer purchasing decisions in Bogor citysimultaneously and partially. The study was conducted on Yamaha N-Max motorcycle owners in Bogor city. Descriptive and verification form research, using instrument test: validity test, reliability test and classic assumptions. This research use 100 respondents as samples, analyzed by using multiple linear regression. The results of the study are the average consumer response to product quality (performance, features, reliability, suitability, durability, servicability, aesthetics, and quality impression) simultaneously has a positive and significant effect on purchasing decisions, while partially performance variabels, features, reliability, conformity, servicability, aesthetics have a positive and significant effect on purchasing decisions. For durability and quality impression variabels do not have a positive and significant effect on purchasing decisions.
\end{abstract}

Keywords: Performance, Features, Reliability, Suitability, Durability, Servicabilty, Aesthetics, Quality Impression, Purchasing Decision.

\begin{abstract}
ABSTRAK
Keputusan pembelian merupakan faktor penting yang mendasari konsumen untuk membeli barang atau jasa dari banyaknya pilihan barang atau jasa yang ada. Penelitian ini dilakukan dengan tujuan untuk mengetahui pengaruh kualitas produk (kinerja, fitur, kehandalan, kesesuian, daya tahan, kemudahan pelayanan, estetika, dan kesan kualitas) sepeda motor Yamaha N-Max pada keputusan pembelian konsumen di Kota Bogor baik secara simultan maupun parsial. Penelitian dilakukan pada pemilik sepeda motor Yamaha N-Max di Kota Bogor. Bentuk penelitian deskriptif dan verifikatif, menggunakan uji istrumen: uji validitas dan uji reliabilitas serta asumsi klasik. Jumlah sampel yang digunakan pada penelitian ini ialah 100 responden. Dianalisis menggunakan regresi linier berganda. Hasil penelitian bahwa rata-rata tanggapan konsumen secara simultan terhadap kualitas produk (kinerja, fitur, kehandalan, kesesuian, daya tahan, kemudahan pelayanan, estetika, dan kesan kualitas) berdampak positif dan nyata terhadap keputusan pembelian, sedangkan secara parsial variabel kinerja, fitur, kehandalan, kesesuian, kemudahan pelayanan, estetika berdampak positif dan nyata terhadap keputusan pembelian. Untuk variabel daya tahan dan kesan kualitas tidak berdampak positif dan nyata terhadap keputusan pembelian.
\end{abstract}

Kata Kunci: Kinerja, Fitur, Kehandalan, Kesesuian, Daya Tahan, Kemudahan Pelayanan, Estetika, Kesan Kualitas, Keputusan Pembelian. 


\section{PENDAHULUAN}

Perkembangan teknologi khususnya moda transportasi saat ini, semakin pesat. Berbagai sarana transportasi seperti kendaraan umum maupun kendaraan pribadi banyak digunakan sebagai alat untuk melakukan pergerakan atau perpindahan. Berdasarkan data dari BPS (2018) menunjukkan jumlah kendaraan di Indonesia pada tahun 2017 mencapai 138.556.669 unit, dimana didominasi oleh sepeda motor yang mencapai $81.5 \%$. Artinya sarana transportasi sepeda motor merupakan sarana yang memiliki atensi terbesar terhadap masyarakat di Indonesia. Selain harga terjangkau, sepeda motor merupakan moda hemat bahan bakar, lebih cepat sampai tujuan dibanding moda umum dan lebih sporty. Tingginya minat terhadap moda sepeda motor di Indonesia, menjadi peluang bisnis bagi perusahaan otomotif. Saat ini, terdapat banyak kompetitor sepeda motor yang berkembang di Indonesia seperti merek Yamaha, Honda, Kawasaki, Suzuki dan TVS. Perkembangan jumlah penjualan sepeda motor selama tahun 2015-2017, fluktuasi mengikuti keadaan ekonomi masyarakat.

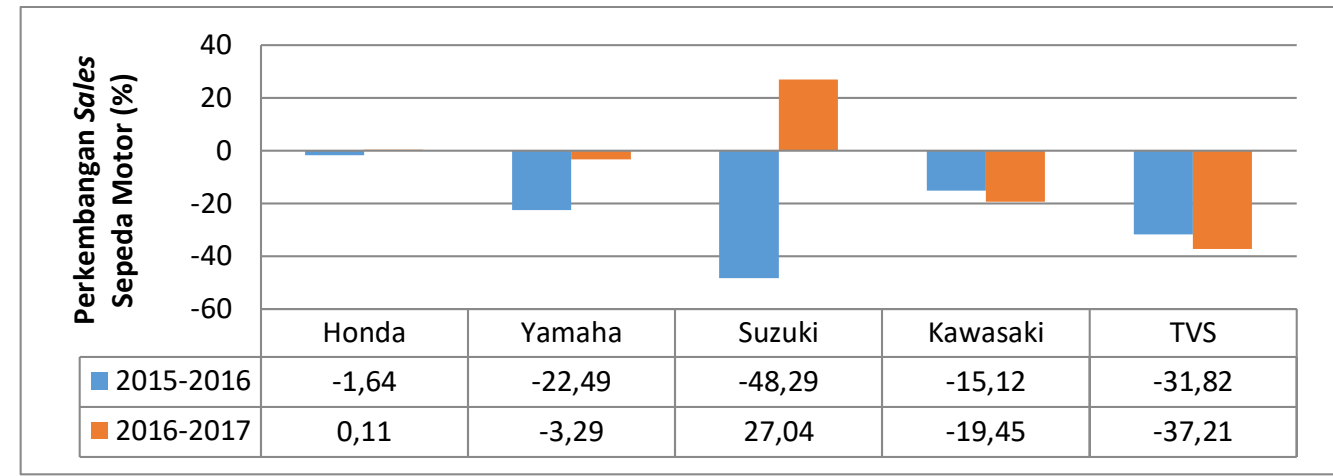

Gambar 1 Persentase Perkembangan Sales Sepeda Motor di Indonesia Periode 2015-2017

Sumber: Data Asosiasi Sepeda Motor Indonesia, 2018

Perkembangan sales sepeda motor pada Indonesia periode tahun 2015-2017 menunjukkan rata-rata jumlah penjualan cenderung mengalami penurunan sebesar $4,62 \%$. Walaupun cenderung menurun namun total permintaannya masih cukup tinggi. Perusahaan sepeda motor di Indonesia memproduksi beberapa jenis sepeda motor yang dipasarkan mulai dari sport, underbone dan matic.

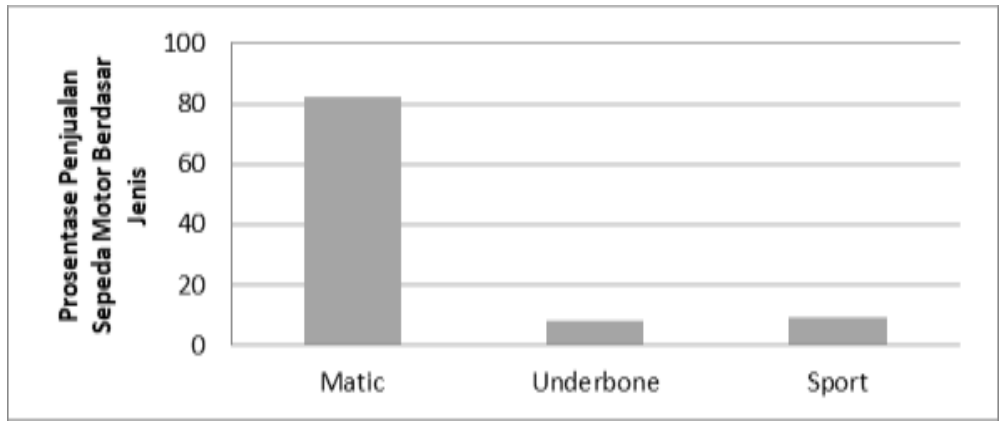

Gambar 2. Data Penjualan Berdasar Jenis Sepeda Motor Tahun 2017 Sumber: Data Asosiasi Sepeda Motor Indonesia, 2018

Berdasarkan Gambar 2 tersebut dapat dilihat bahwa penjualan jenis sepeda motor tertinggi pada tahun 2017 yaitu jenis matic sebesar $82,37 \%$, diikuti jenis sepeda motor Sport sebesar 9,20\% dan jenis sepeda motor dengan penjualan terendah yaitu underbone sebesar $8,43 \%$. Perusahaan sepeda motor memproduksi sepeda motor tipe matic dengan kapasitas mesin $125 \mathrm{cc}$ dan $150 \mathrm{cc}$.

Tabel 1 Data Sales Sepeda Motor Matic 150cc Tahun 2017

\begin{tabular}{clcc}
\hline No. & \multicolumn{1}{c}{ Tipe Motor } & Jumlah (Unit) & Persentase (\%) \\
\hline 1. & Honda PCX & 4.848 & 1,08 \\
2. & Honda SH150i CBU & 140 & 0,03
\end{tabular}




\begin{tabular}{rlcc} 
3. & Yamaha N-Max & 282.097 & 62,98 \\
4. & Yamaha X-Max & 10.236 & 2,29 \\
5. & Yamaha Aerox & 150.582 & 33,62 \\
\hline Total & & $\mathbf{4 4 7 . 9 0 3}$ & $\mathbf{1 0 0}$ \\
\hline
\end{tabular}

Sumber: Data Asosiasi Sepeda Motor Indonesia, 2018

Berdasarkan Tabel 1 dapat diketahui bahwa Yamaha N-Max merupakan sepeda motor matic $150 \mathrm{cc}$ dengan penjualan tertinggi sebesar $62,98 \%$, sedangkan Honda SH150i merupakan sepeda motor matic $150 \mathrm{cc}$ dengan penjualan terendah sebesar $0,03 \%$. Sepeda motor Yamaha N-Max merupakan sepeda motor matic premium pertama dari seri maxi Yamaha dan menjadi produk andalan yang berkontribusi besar dalam penjualan sepeda motor matic Yamaha, tetapi hal ini ternyata tidak diikuti dengan jumlah unit yang mencapai target penjualan pada tahun 2017 .

Tabel 2 Realisasi-Target Jumlah Penjualan Motor Matic Yamaha N-Max Tahun 2015 - 2017

\begin{tabular}{|c|c|c|c|c|}
\hline \multirow{2}{*}{ Tahun } & \multicolumn{2}{|c|}{ JumlahPenjualan (Unit) } & \multirow{2}{*}{ Ketercapaian Target (\%) } & \multirow{2}{*}{ Keterangan } \\
\hline & Realisasi & Target & & \\
\hline 2015 & 89.286 & 80.000 & 111,61 & Tercapai \\
\hline 2016 & 254.826 & 250.000 & 101,93 & Tercapai \\
\hline 2017 & 282.097 & 270.000 & 104,48 & Tercapai \\
\hline 2018 & 261.542 & 270.000 & 96,87 & Tidak Tercapai \\
\hline
\end{tabular}

Sumber: Data AsosiasiSepeda Motor Indonesia, 2018.

Berdasarkan Tabel 2 pencapaian target penjualan motor matic Yamaha N-Max pada tahun 2015 sebesar $111,61 \%$, pada tahun 2016 sebesar $101,93 \%$, dan pada tahun 2017 sebesar $104,48 \%$. Sedangkan pada tahun 2018 pencapaian target penjualan motor matic Yamaha N-Max hanya sebesar 96,87\% dengan ketidaktercapaian sebesar 3,13\%. Salah satufaktor yang diduga menyebabkan ketidaktercapaian target adalah munculnya sepeda motor merek lain sejenis yang lebih unggul seperti: Honda PCX Hybrid, Honda Vario, Vespa LX150 3V dan Benelli X150, sehingga standar sepeda motor Yamaha NMax berada dibawah standar sepeda motor lain yang lebih dipercaya. Hal ini mendorong produsen Yamaha untuk terus memperbaiki dan meningkatkan kualitas produk dari Yamaha N-Max melalui standarisasi dan peningkatan kualitas produk, yang dimaksudkan untuk meningkatkan kualitas dan pangsa pasarnya, serta agar tetap dapat bersaing ditengah munculnya produk-produk baru sepeda motor matic yang berkembang pesat.

\section{MATERI DAN METODE}

\section{Produk}

Berdasarkan hasil prasurvey yang dilakukan terhadap kualitas produk Yamaha N-Max kepada anggota komunitas. Penjualan Yamaha N-Max yang belum mencapai target menggambarkan kurangnya minat masyarakat untuk membeli diduga dipengaruhi oleh faktor kualitas produk yang terdapat pada N-Max. Motor Matic N-Max di Kota Bogor menunjukkan bahwa, masih terdapat penilaian konsumen terkait kualitas produk yang harus menjadi perhatian perusahaan untuk segera diperbaiki seperti dalam hal kinerja untuk kemudahan pengoperasian, stang atau roda depan N-Max kurang stabil di kecepatan tinggi, sedangkan untuk kehandalannya, rem Yamaha N-Max kurang agresif yang dapat berpengaruh pada keselamatan pengguna. Selain itu, dalam hal estetika bunyi mesin N-Max kurang halus, tidak ada power output, tidak ada laci tertutup di depan, kualitas material plastik di beberapa bagian dan cat yang mudah memudar. Permasalahan inilah yang diduga mempengaruhi kurangnya pemilihan produk dan pemilihan merek oleh konsumen dalam memutuskan pembelian Yamaha N-Max.

Produk adalah hal apapun yang dapat ditawarkan ke pasar untuk mencari 
perhatian, diperdagangkan, dikonsumsi yang dapat memuaskan keinginan dan kebutuhan (Kotler dan Armstrong, 2012:248)

\section{Atribut Produk}

Atribut produk memiliki karakteristikkarakteristik menurut Kotler dan Armstrong (2012:206) karakteristik atribut produk terdiri dari kualitas produk (quality product), fitur produk(features product), gaya dan rancangan (style and design).

\section{Kualitas Produk}

Kualitas produk adalah karakteristik produk dan jasa yang menunjang kemampuannya untuk memuaskan kebutuhan pelanggan (Kotler dan Armstrong, 2012:165)

\section{Dimensi Kualitas Produk}

Terdapat delapan dimensi dalam pengembangan kualitas produk yang dapat digunakan sebagai dasar perencanaan strategis (Tjiptono, 2009:68). Kedelapan dimensi tersebut sebagai berikut:

1. Kinerja ialah bagian fungsional pada produk dan merupakan kriteria utama yang dinilai pelanggan ketika akan menggunakan suatu produk.

2. Fitur ialah bagaian dari kinerja yang memiliki fungsi dasar, berhubungan dengan pilihan dan pengembangannya.

3. Kehandalan berhubungan dengan probabilitas suatu produk berfungsi dengan layak pada suatu periode waktu didalam kondisi tertentu.

4. Kesesuaian berkaitan dengan kinerja serta kualitas produk yang memiliki standar dan spesifikasi yang sudah ditentukan.

5. Daya tahan merupakan waktu penggunaan suatu produk hingga harus diganti, diukur dengan umur daya tahan produk.
6. Kemudahan pelayanan ialah sesuatu yang berhubungan dengan pelayanan perbaikan yang meliputi kecepatan, kompetensi, kemudahan dan akurasi dalam perbaikan hal ini sering dikaitkan dengan layanan penjualan yang tersedia di pasar.

7. Estetika ialah mengenai keindahan yang bersikap subjektif sehingga berkaitan dengan penilaian pribadi serta refleksi atas pilihan individual serta seperti tampilan bunyi, rasa, atau bau suatu produk.

8. Kesan Kualitas adalah kesan produk yang dialami oleh pelanggan, dimensi kualitas berhubungan dengan presepsi pelanggan terhadap kualitas produk atau merek serta terkait citra dan reputasi produk dan tanggung jawab perusahaan pada produk yang dipasarkan.

\section{Keputusan Pembelian}

Menurut Tjiptono (2015:19), keputusan pembelian merupakan salah satu bagian dari perilaku konsumen, dimana perilaku konsumen sendiri ialah perlakuan personal dengan langsung terlibat untuk mendapatkan, memakai, dan menentukan produk serta jasa termasuk proses pengambilan keputusan yang mendahului dan mengikuti tindakan tersebut.

\section{Dimensi Keputusan Pembelian}

Keputusan pembelian memiliki dimensi yaitu pemilihan produk, pilihan merek, pemilihan penyalur, jumlah pembeliaan, waktu pembelian, metode pembayaran (Kotler dan Keller, 2012:178) 

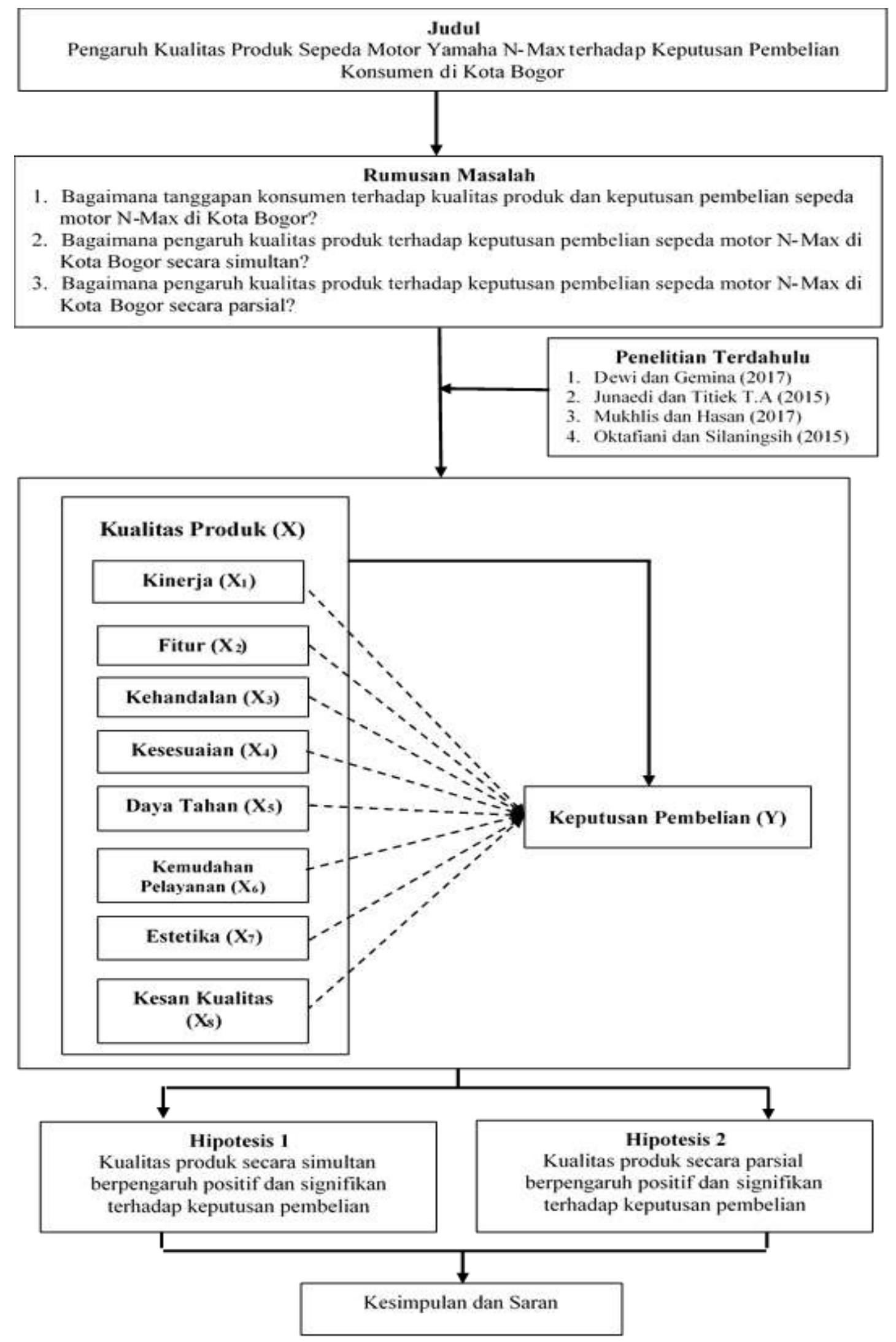

Gambar 4 Kerangka Pemikiran

Metode Penelitian

Penelitian ini menganalisis pengaruh kualitas produk pada keputusan pembelian, 
dengan objek penelitiannya adalah pengguna sepeda motor matic Yamaha N-Max yang tergabung dalam komunitas di Kota Bogor. Penelitian ini dilakukan untuk memperoleh gambaran mengenai pengaruh kualitas produk sepeda motor matic Yamaha N-Max pada keputusan pembelian di Kota Bogor. Dalam penelitian ini digunakan bentuk penelitian deskriprif dan verifikatif dengan pendekatan kuantitatif. Penelitian ini menggunakan metode survey. Metode survey ialah teknik yang digunakan untuk mencari data dari suatu tempat secara alamiah, tetapi penulis melakukan pengumpulan data, seperti: menyebarkan kuesioner, wawancara terstruktur dan sebagainya, (Sugiyono, 2014:6).

Adapun populasi dalam penelitian ini ialah pengendara sepeda motor matic

$$
n=\frac{N}{1+N e^{2}}
$$

$\mathrm{n}=99,733$ dibulatkan menjadi 100

Dimana:

$\mathrm{n}=$ Ukuran Sampel

$\mathrm{N}=$ Ukuran Populasi
Yamaha N-Max di Kota Bogor yang tergabung dalam komunitas yang terdiri dari 374 anggota. Tehnik pengambilan sampel dengan menggunakan teknik non-probability sampling. Teknik non-probability sampling ialah metode pengambilan sampel yang tidak memiliki kesempatan atau peluang yang sama bagi setiap anggota populasi, dengan purposive sampling dimana sampel yang dipilih berdasarkan karakteristiknya. Karakteristik tersebut antara lain harus memiliki sepeda motor matic Yamaha Nmax, tergabung dalam komunitas resmi Yamaha matic N-Max di kota Bogor, dan keanggotaan minimal 5 bulan. Pengukuran sampel dilakukan dengan menggunakan teknik Slovin sebagai berikut:

$$
n=\frac{374}{1+374(0,1)^{2}}=99,733
$$

$\mathrm{e}=$ Persen kelonggaran ketidaktelitian karena kesalahan pengambilan sampel yang masih dapat ditolerir atau diinginkan misalnya $(10 \%$ atau $e=0,1)$.

Tabel 3 Data Jumlah Sampel Konsumen Sepeda Motor Yamaha N-Max

\begin{tabular}{lccc}
\hline \multirow{2}{*}{ Komunitas } & \multicolumn{3}{c}{ Anggota (orang) } \\
\cline { 2 - 4 } & Jumlah Total & Perhitungan & JumlahSampel \\
\hline YNCI & 135 & $135 / 374 * 100$ & 36 \\
Max Republic & 64 & $64 / 374 * 100$ & 17 \\
Bogor Max Owner & 94 & $94 / 374 * 100$ & 25 \\
Nmax Rider Bogor & 81 & $81 / 374 * 100$ & 22 \\
\hline \multicolumn{1}{c}{ Total } & $\mathbf{3 7 4}$ & & $\mathbf{1 0 0}$ \\
\hline
\end{tabular}

Sumber: Asosiasi Pengguna Yamaha N-Max Bogor, 2018

Data yang digunakan dalam penelitian ialah data primer dan data sekunder dengan cara studi kepustakaan dan studi lapangan melalui wawancara, observasi dan penyebaran kuesioner. Pengujian data menggunakan uji validitas, reliabilitas, uji asumsi klasik yaitu uji normalitas, uji multikoliniaritas dan uji heterokedastisitas. Setelah pengujian tersebut dilakukan selanjutnya dilakukan regresi linear berganda, korelasi berganda, koefisien determinasi, pengujian hipotesis secara simultan (Uji F) dan terakhir adalah pengujian secara parsial (Uji t). Dalam penyebaran kuesioner dilakukan pada komunitas sepeda matic motor Yamaha NMax di Kota Bogor. Berdasar jenis kuesioner yang digunakan ialah kuesioner tertutup dengan skala ordinal diangkat menjadi skala interval dan menggunakan Method of Successive Interval. Skala pengukuran untuk penelitian ini ialah menggunakan dengan lima tingkatan. Operasionalisasi variabel penelitian ini disajikan pada Tabel 4 berikut ini:

Tabel 4 Operasionalisasi Variabel Penelitian

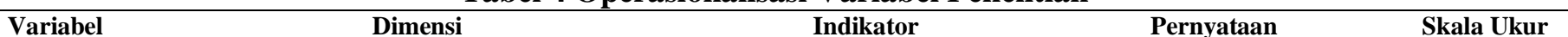




\begin{tabular}{|c|c|c|c|c|}
\hline \multirow[t]{8}{*}{$\begin{array}{l}\text { Kualitas } \\
\text { Produk }(\mathrm{X})\end{array}$} & $\begin{array}{l}\text { Kinerja }\left(\mathrm{X}_{1}\right) \text { merupakan bagian fungsional pada } \\
\text { produk dan merupakan kriteria utama yang dinilai } \\
\text { konsumen ketika akan membeli produk. (Tjiptono, } \\
2009: 68 \text { ) }\end{array}$ & $\begin{array}{l}\text { 1. Aspek fungsional } \\
\text { 2. Karakteristik utama }\end{array}$ & $\begin{array}{l}\text { 1. Kemudahan pengoperasian } \\
\text { 2. Akselerasi dan tarikan } \\
\text { 3. Konsumsi bahan bakar }\end{array}$ & $\begin{array}{l}\text { Ordinal Likert } \\
(1-5)\end{array}$ \\
\hline & $\begin{array}{l}\text { Fitur }\left(\mathrm{X}_{2}\right) \text { merupakan bagian kedua pada kinerja } \\
\text { yang meningkatkan fungsi dasar, berhubungan } \\
\text { dengan pilihan-pilihan dan pengembangannya. } \\
\text { (Tjiptono, 2009:68) }\end{array}$ & $\begin{array}{l}\text { 1. Fungsi dasar } \\
\text { 2. Pilihan dan } \\
\text { pengembangan }\end{array}$ & $\begin{array}{l}\text { 1. Teknologi ABS } \\
\text { 2. Ukuran bagasi } \\
\text { 3. Lampu LED }\end{array}$ & $\begin{array}{l}\text { Ordinal Likert } \\
(1-5)\end{array}$ \\
\hline & $\begin{array}{l}\text { Kehandalan }\left(\mathrm{X}_{3}\right) \text { berhubungan dengan probabilitas } \\
\text { suatu produk berfungsi dengan layak pada suatu } \\
\text { periode waktu didalam kondisi tertentu. (Tjiptono, } \\
\text { 2009:68) }\end{array}$ & $\begin{array}{l}\text { 1. } \begin{array}{l}\text { Berfungsi dalam periode } \\
\text { tertentu }\end{array} \\
\text { 2. Berfungsi dalam kondisi } \\
\text { tertentu }\end{array}$ & $\begin{array}{l}\text { 1. Ketahanan mesin } \\
\text { 2. Handal di segala jenis } \\
\text { medan jalan }\end{array}$ & $\begin{array}{l}\text { Ordinal Likert } \\
(1-5)\end{array}$ \\
\hline & $\begin{array}{l}\text { Kesesuaian }\left(\mathrm{X}_{4}\right) \text { berkaitan dengan kinerja serta } \\
\text { kualitas produk berstandar sesuai diharapkan } \\
\text { pelanggan pada dasarnya produk memiliki standar } \\
\text { dan spesifikasi yang sudah ditentukan. (Tjiptono, } \\
\text { 2009:68) }\end{array}$ & $\begin{array}{l}\text { 1. Kinerja } \\
\text { 2. Kesesuaian produk sesuai } \\
\text { standar }\end{array}$ & $\begin{array}{l}\text { 1. Kesesuaian spesifikasi } \\
\text { 2. Kesesuaian desain }\end{array}$ & $\begin{array}{l}\text { Ordinal Likert } \\
(1-5)\end{array}$ \\
\hline & $\begin{array}{l}\text { Daya tahan }\left(\mathrm{X}_{5}\right) \text { merupakan waktu penggunaan } \\
\text { suatu produk hingga harus diganti, diukur dengan } \\
\text { umur daya tahan produk. (Tjiptono, 2009:68) }\end{array}$ & $\begin{array}{l}\text { 1. Umur teknis } \\
\text { 2. Umur ekonomis }\end{array}$ & $\begin{array}{l}\text { 1. Masa pakai } \\
\text { 2. Intensitas kerusakan } \\
\text { rendah }\end{array}$ & $\begin{array}{l}\text { Ordinal Likert } \\
(1-5)\end{array}$ \\
\hline & $\begin{array}{l}\text { Kemudahan pelayanan }\left(\mathrm{X}_{6}\right) \text { sesuatu yang } \\
\text { berhubungan dengan pelayanan perbaikan yang } \\
\text { meliputi kecepatan, kompetensi, kemudahan dan } \\
\text { akurasi dalam perbaikan hal ini sering dikaitkan } \\
\text { dengan layanan penjualan yang tersedia di pasar. } \\
\text { (Tjiptono, 2009:68) }\end{array}$ & $\begin{array}{l}\text { 1. Pelayanan perbaikan } \\
\text { 2. Akurasi dalam perbaikan }\end{array}$ & $\begin{array}{l}\text { 1. Pelayanan memuaskan } \\
\text { 2. Kemudahan dalam } \\
\text { perbaikan } \\
\text { 3. Akurasi dalam perbaikan } \\
\text { dan perawatan }\end{array}$ & $\begin{array}{l}\text { Ordinal Likert } \\
(1-5)\end{array}$ \\
\hline & $\begin{array}{l}\text { Estetika }\left(\mathrm{X}_{7}\right) \text { keindahan yang bersikap subjektif } \\
\text { sehingga berkaitan dengan penilaian pribadi serta } \\
\text { refleksi atas pilihan individual serta seperti } \\
\text { tampilan bunyi, rasa, atau bau suatu produk. } \\
\text { (Tjiptono, 2009:68) }\end{array}$ & $\begin{array}{l}\text { 1. Keindahan } \\
\text { 2. Tampilan }\end{array}$ & $\begin{array}{l}\text { 1. Varian warna } \\
\text { 2. Desain sporty } \\
\text { 3. Suar amesin }\end{array}$ & $\begin{array}{l}\text { Ordinal } \\
\text { Likert }(1-5)\end{array}$ \\
\hline & $\begin{array}{l}\text { Kesan kualitas }\left(\mathrm{X}_{8}\right) \text { kualitas produk yang dialami } \\
\text { oleh pelanggan, dimensi kualitas berhubungan } \\
\text { dengan presepsi pelanggan terhadap kualitas } \\
\text { produk atau merek serta terkait citra dan reputasi } \\
\text { produk dan tanggung jawab perusahaan pada } \\
\text { produk yang dipasarkan. (Tjiptono, 2009:68) }\end{array}$ & $\begin{array}{ll}\text { 1. } & \text { Kualitas produk } \\
\text { 2. } & \text { Reputasi produk } \\
\text { 3. } & \text { Tanggung jawab }\end{array}$ & $\begin{array}{l}\text { 1. Reputasi merek } \\
\text { 2. Tanggung jawab } \\
\text { perusahaan }\end{array}$ & $\begin{array}{l}\text { Ordinal Likert } \\
(1-5)\end{array}$ \\
\hline \multirow[t]{6}{*}{$\begin{array}{l}\text { Keputusan } \\
\text { Pembelian } \\
\text { (Y) }\end{array}$} & $\begin{array}{l}\text { Pemilihan Produk. } \\
\text { Konsumen bisa mimilih untuk membeli sebuah } \\
\text { produk atau jasa untuk tujuan yang lain. (Kotler } \\
\text { dan Keller, 2012:178) }\end{array}$ & $\begin{array}{l}\text { 1. Keunggulan produk } \\
\text { 2. Manfaat produk }\end{array}$ & $\begin{array}{l}\text { 1. Memenuhi kebutuhan } \\
\text { berkendara } \\
\text { 2. Memiliki keunggulan yang } \\
\text { dibutuhkan }\end{array}$ & $\begin{array}{l}\text { Ordinal Likert } \\
(1-5)\end{array}$ \\
\hline & $\begin{array}{l}\text { Pilihan Merek. } \\
\text { Konsumen harus memutuskan merek dari produk } \\
\text { serta jasa yang akan dibeli. (Kotler dan Keller, } \\
\text { 2012:178) }\end{array}$ & $\begin{array}{l}\text { 1. Ketertarikan pada merek } \\
\text { 2. Kebiasaan pada merek }\end{array}$ & $\begin{array}{ll}\text { 1. } & \text { Merk yang popular } \\
\text { 2. } & \text { Merk yang dipercaya }\end{array}$ & \\
\hline & $\begin{array}{l}\text { Pilihan Penyalur. } \\
\text { Konsumen memutusan tentang penyalur yang } \\
\text { akan digunakan. (Kotler dan Keller, 2012:178) }\end{array}$ & $\begin{array}{l}\text { 1. Kemudahan untuk } \\
\text { mendapatkan produk } \\
\text { yang diinginkan } \\
\text { 2. Ketersediaan barang }\end{array}$ & $\begin{array}{l}\text { 1. Lokasi dealer mudah } \\
\text { dijangkau } \\
\text { 2. Produk tersedia disemua } \\
\text { dealer }\end{array}$ & \\
\hline & $\begin{array}{l}\text { Jumlah Pembelian. } \\
\text { Pelanggan dapat memutusan tentang banyaknya } \\
\text { produk atau jasa yang akan dibelinya pada suatu } \\
\text { saat. (Kotler dan Keller, 2012:178) }\end{array}$ & $\begin{array}{l}\text { 1. Keputusan jumlah } \\
\text { pembelian }\end{array}$ & $\begin{array}{l}\text { 1. Membeli dengan jumlah } \\
\text { yang dibutuhkan }\end{array}$ & \\
\hline & $\begin{array}{l}\text { Waktu Pembelian. } \\
\text { Keputusan pelanggan untuk menentukan waktu } \\
\text { bisa berbeda-beda. (Kotler dan Keller, 2012:178) }\end{array}$ & $\begin{array}{l}\text { 1. Keuntungan yang } \\
\text { dirasakan }\end{array}$ & $\begin{array}{l}\text { 1. Membeli pada saat ada } \\
\text { potongan harga }\end{array}$ & \\
\hline & $\begin{array}{l}\text { Metode Pembayaran. } \\
\text { Konsumen dalam melakukan pembelian suatu } \\
\text { produk pasti harus melakukan suatu pembayaran. } \\
\text { (Kotler dan Keller, 2012:178) }\end{array}$ & $\begin{array}{l}\text { 1. Proses pembelian } \\
\text { 2. Ketersediaan fasilitas } \\
\text { pembayaran }\end{array}$ & $\begin{array}{l}\text { 1. Proses pembelian yang } \\
\text { mudah } \\
\text { 2. Dealer menyediakan } \\
\text { berbagai fasilitas } \\
\text { pembayaran }\end{array}$ & \\
\hline
\end{tabular}

HASIL DAN PEMBAHASAN Karakteristik Konsumen
Karakteristik konsumen dalam penelitian ini mayoritas laki-laki sebanyak 86 orang, berusia 20-29 tahun, pekerjaan 


\section{karyawan swasta dan memiliki Tanggapan Konsumen terhadap pendapatanRp. 4.500.000-6.500.000/bulan. \\ Kualitas Produk Serta Keputusan Pembelian}

Berikut rekapitulasi tanggapan

konsumen pada variabel kualitas produk:

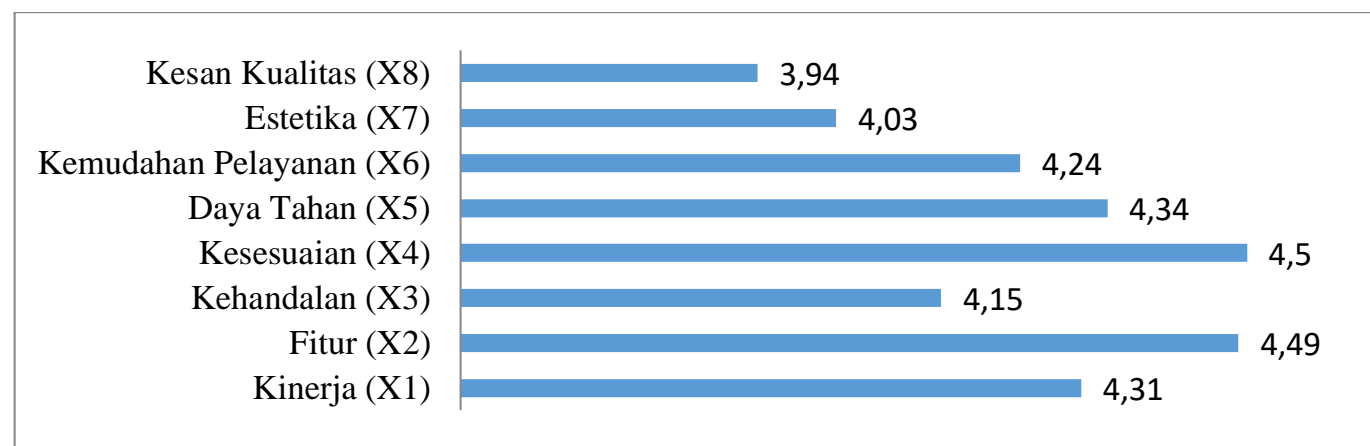

Gambar 5 Rekapitulasi Tanggapan Konsumen pada Variabel Kualitas Produk

Sumber: Data Diolah, 2019

Berdasarkan Gambar 5 dapat disimpulkan bahwa jawaban konsumen untuk variabel kinerja memilki nilai rata-rata skor tanggapan sebesar 4,31 (sangat baik), jawaban konsumen untuk variabel fitur memiliki rata-rata skor tanggapan sebesar 4,49 (sangat baik), jawaban konsumen untuk variabel kehandalan meniliki nilai rata-rata skor tanggapan sebesar 4,15 (baik), jawaban konsumen untuk variabel kesesuaian memiliki nilai rata-rata skor tanggapan sebesar 4,50 (sangat baik), jawaban konsumen untuk variabel daya tahan memiliki nilai rata-rata skor tanggapan sebesar 4,34 (sangat baik), jawaban konsumen untuk variabel kemudahan pelayanan memiliki nilai rata-rata skor tanggapan sebesar 4,24 (sangat baik), jawaban konsumen untuk variabel estetika memiliki nilai rata-rata skor tanggapan sebesar 4,03 (baik), sedangkan jawaban konsumen untuk variabel kesan kualitas memiliki nilai rata-rata skor tanggapan sebesar 3,94 (baik), sehingga dapat disimpulkan bahwa kualitas suatu produk serta jasa terdiri dari: kinerja, fitur, kehandalan, kesesuaian, daya tahan, kemudahan pelayanan, estetika dan kesan kualitas merupakan faktor yang penting dalam meningkatkan keputusan pembelian konsumen.

Penilaian konsumen tertinggi terdapat pada dimensi kesesuaian. Hal ini dikarenakan Yamaha N-Max telah dilengakapi speedo meter digital, tachometer digital, odometer digital, tripmeter digital untuk sistem pembakaran, Yamaha NMax telah mengadopsi sistem full injection sehingga penggunaan bahan bakar dapat lebih hemat dan memilki power yang besar. Sedangkan penilaian konsumen terendah terdapat pada dimensi kesan kualitas. Hal ini dikarenakan kurangnya perusahaan melakukan interaksi kepada masyarakat mengenai kualitas produk yang dimiliki sepeda motor Yamaha N-Max. Sedangkan tanggapan konsumen terhadap keputusan pembelian adalah sebagai berikut:

Berbagai macam fasilitas pembayaran Proses pembelian yang mudah Potongan harga Jumlah yang dibutuhkan Ketersediaan stok Lokasi dealer Yamaha mudah dijangkau Kepercayaan merek Yamaha Merek yang popular Keunggulan yang dibutuhkan Kebutuhan berkendara

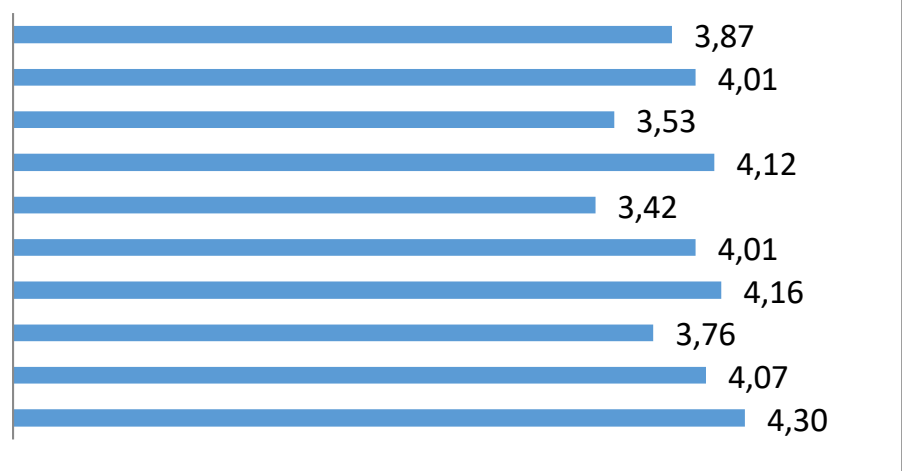

Gambar 6 Rekapitulasi Tanggapan Konsumen Terhadap Variabel Keputusan Pembelian Sumber: Data Diolah, 2019 
Berdasarkan Gambar 6 dapat diketahui bahwa kebutuhan berkendara adalah indicator dengan nilai penilaian konsumen tertinggi $(4,30)$, sedangkan yang terendah ialah indicator ketersedian stok $(3,42)$, dengan skor rata-rata penilaian konsumen terhadap variabel keputusan pembelian sebesar 3,93 yang termasuk kategori baik sehingga diketahui bahwa sepeda motor matic Yamaha N-Max cocok dipakai sebagai sarana transportasi sehari-hari. Kebutuhan untuk berkendara mendapat tanggapan tertinggi, ini ditunjukkan dengan beragamnya aktivitas kerja setiap orang memungkinkan segala aktivitas tersebut harus dilakukan secara cepat, maka dari itu otomotif sangat dibutuhkan dalam menunjang kegiatan masyarakat, untuk mendapatkan waktu yang efektif dan efisien. Sedangkan indikator yang mendapatkan nilai terendah pada ketersediaan stok, ini ditunjukkan dengan Yamaha N-Max yang tidak selalu tersedia pada setiap dealer Yamaha, sehingga konsumen jika ingin membeli Yamaha NMax harus memesannya terlebih dahulu dan menunggu cukup lama hingga sampai ke tangan pembeli. Hal ini jelas menjadi kendala dalam hal pelanggan dalam memutuskan untuk membeli N-Max dan dapat berpaling pada produk kompetitor. Pada permasalahan ini perusahaan sebaiknya dapat meningkatkan kembali ketersediaan sepeda motor matic Yamaha N-Max agar permintaan konsumen dapat terpenuhi.

\section{Uji Validitas dan Reliabilitas Instrumen Penelitian}

Uji validitas dilakukan dengan tujuan mengukur pernyataan atau pertanyaan dalam kuesioner. Validitas sebuah data dinyatakan terpenuhi jika pernyataan atau pertanyaan itu bisa ungkap sesuatu. Berdasarkan pengujian instrument kepada tiga puluh (30) responden menunjukkan bahwa uji validitas terkait variabel bebas kualitas produk dan variabel terikat yakni keputusan pembelian bisa dikatakan valid, dapat dilanjutkan kepengujian reliabilitas. Menurut Sugiyono (2014:173), instrumen yang reliabel ialah instrumen apabila digunakan berulang kali untuk mengukur objek yang serupa, maka menampilkan data yang serupa dan dapat dipakai untuk pengumpulan data. Berdasarkan pengujian instrument penelitian kepada tiga puluh (30) responden menunjukkan bahwa dari seluruh kualitas produk serta keputusan pembelian diperoleh hasil jika seluruh item reliabel karena memiliki Cronbach Alpha >0,6.

\section{Uji Asumsi Klasik}

Hasil uji yaitu: a) Uji normalitas bahwa data dinyatakan terdistribusi normal; b) Uji multi kolonieritas tidak multi koloni antara variabel bebasnya; c) Uji heterokedastisitas tidak heterokedastisitas dari semua model regresi sehingga semua model regresi dapat dilanjutkan ke uji regresi linear berganda.

Analisis data menggunakan SPSS versi 20 diperoleh persamaan berikut:

Tabel 5 Rangkuman Hasil Perhitungan Kualitas Produk Pada Keputusan Pembelian Coeficients $^{\mathrm{a}}$

\begin{tabular}{|c|c|c|c|c|c|}
\hline \multirow[t]{2}{*}{ Model } & \multicolumn{2}{|c|}{$\begin{array}{c}\text { Unstandardized } \\
\text { Coefficients }\end{array}$} & \multirow{2}{*}{$\begin{array}{c}\begin{array}{c}\text { Standardized } \\
\text { Coefficients }\end{array} \\
\text { Beta } \\
\end{array}$} & \multirow{2}{*}{$t_{\text {hitung }}$} & \multirow[t]{2}{*}{ Sig. } \\
\hline & B & Std. Error & & & \\
\hline (Constant) & $-5,483$ & 4,884 & - & $-1,123$ & 0,265 \\
\hline Kinerja & 0,503 & 0,136 & 0,272 & 3,704 & 0,000 \\
\hline Fitur & 0,902 & 0,170 & 0,384 & 5,312 & 0,000 \\
\hline Kehandalan & 0,479 & 0,153 & 0,228 & 3,121 & 0,002 \\
\hline Kesesuaian & 0,423 & 0,212 & 0,143 & 1,990 & 0,050 \\
\hline Daya Tahan & 0,251 & 0,172 & 0,106 & 1,460 & 0,148 \\
\hline Kemudahan Pelayanan & 0,562 & 0,135 & 0,303 & 4,160 & 0,000 \\
\hline
\end{tabular}




\begin{tabular}{|c|c|c|c|c|c|}
\hline Estetika & 0,562 & 0,092 & 0,467 & 6,106 & 0,000 \\
\hline Kesan Kualitas & 0,254 & 0,169 & 0,110 & 1,504 & 0,136 \\
\hline$t_{\text {tabel }}$ & $=1,661$ & & & & \\
\hline F & $=14,052$ & & & & \\
\hline Sig & $=0,000$ & & & & \\
\hline $\mathrm{F}_{\text {tabel }}$ & $=2,042$ & & & & \\
\hline $\mathrm{R}$ & $=0,743$ & & & & \\
\hline $\mathrm{R}^{2}$ & $=0,553$ & & & & \\
\hline Adjusted $\mathrm{R}^{2}$ & $=0,513$ & & & & \\
\hline Alpha $(\alpha)$ & $=5 \%$ & & & & \\
\hline
\end{tabular}

Sumber: Data diaolah, 2019

Berdasarkan Tabel 5, diperoleh suatu persamaan regresi dengan model taksiran sebagai berikut:

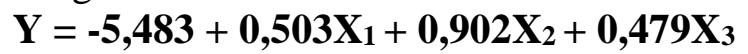
$+0,423 X_{4}+0,251 X_{5}+0,562 X_{6}+0,562 X_{7}+$

$$
0,254 \mathrm{X}_{8}+\mathcal{E}
$$

Berdasarkan persamaan tersebut dapat diketahui bahwa kinerja, fitur, kehandalan, kesesuaian, daya tahan, kemudahan pelayanan, estetika dan kesan kualitas memiliki dampak positif pada keputusan pembelian. Hasil korelasi (r) menunjukkan sebesar 0,743; yang berada pada interval nilai r (0,600-0,799) kuat. Artinya semakin tinggi kinerja, fitur, kehandalan, kesesuaian, daya tahan, kemudahan pelayanan, estetika, dan kesan kualitas, bahwa keputusan pembelian sepeda motor matic Yamaha N-Max semakin meningkat dan sebaliknya. Sedangkan nilai R Square sebesar 0,553 atau 55,3\%. Hal ini menunjukkan bahwa persentase sumbangan dari variabel kinerja, fitur, kehandalan, kesesuaian, daya tahan, kemudahan pelayanan, estetika, dan kesan kualitas pada keputusan pembelian sepeda motor matic Yamaha N-Max di kota Bogor sebesar $55,3 \%$; sedangkan sisanya $44,7 \%$ dijelaskan oleh faktor lain seperti: budaya, sosial, kepribadian dan psikologis (Kotler dan Keller, 2012:151)

\section{Pengaruh Kualitas Produk Terhadap Keputusan Pembelian}

Berdasarkan hasil pengujian diketahui bahwa nilai $F_{\text {hitung }}$ sebesar 14,052 dan nilai $\mathrm{F}_{\text {tabel }}$ untuk $\mathrm{a}=0,05$ dengan derajat kebebasan df1: $9-1=8$ dan df2: $100-8-1=91$ sebesar 2,042 sehingga dapat diketahui bahwa $F_{\text {hitung }}>F_{\text {tabel }} \quad(14,052>2,042)$ dan Sig $F$
$0,000<0,05$; maka dapat disimpulkan bahwa Ho ditolak serta Ha diterima yang menyatakan bahwa kinerja, fitur, kehandalan, kesesuaian, daya tahan, kemudahan pelayanan, estetika, dan kesan kualitas secara simultan berdampak positif dan nyata terhadap keputusan pembelian.

\section{Keputusan Pembelian (Y)}

Berdasarkan hasil pengujian dapat diketahui bahwa nilai $t_{\text {hitung }}$ untuk variabel kinerja $\left(\mathrm{X}_{1}\right)$ sebesar 3,704 dan nilai $\mathrm{t}_{\text {tabel }}$ untuk $\mathrm{a}=0,05$ dengan derajat kebebasan (n-k-1) $100-8-1=91$ sebesar 1,661 berarti $t_{1 \text { hitung }}>t_{\text {tabel }}$ (3,704>1,661), maka Ho ditolak serta $\mathrm{Ha}$ diterima, jadi kinerja berdampak positif dan nyata terhadap keputusan pembelian. Hal ini ditketahui pada nilai koefisien regresi sebesar 0,503 serta memiliki nilai probabilitas 0,000 $<0,05$. Hasil penelitian yang diperoleh menemukan bahwa faktor kinerja mempunyai kontribusi yang nyata pada keputusan pembelian.

\section{Pengaruh Fitur $\left(\mathrm{X}_{2}\right)$ terhadap Keputusan Pembelian (Y)}

Berdasar hasil pengujian dapat diketahui bahwa nilai $t_{2 h i t u n g}$ untuk variabel fitur $\left(\mathrm{X}_{2}\right)$ sebesar5,312 dan nilai $\mathrm{t}_{\text {tabel }}$ untuk $\mathrm{a}=0,05$ dengan derajat kebebasan (n-k-1) $100-8-1=91$ sebesar 1,661 berarti $t_{2 h i t u n g}>t_{\text {tabel }}$ $(5,312>1,661)$, maka Ho ditolak serta Ha diterima, jadi fitur berdampak positif dan nyata pada keputusan pembelian. Hal ini diketahui bahwa nilai koefisien regresi sebesar 0,902 serta memiliki nilai probabilitas $0,000<0,05$. Hasil penelitian yang diperoleh menemukan bahwa faktor fitur mempunyai kontribusi yang nyata pada keputusan pembelian. 


\section{Pengaruh Kehandalan $\left(\mathrm{X}_{3}\right)$ terhadap Keputusan Pembelian (Y)}

Berdasarkan hasil pengujian dapat diketahui bahwa nilai $t_{3 h i t u n g}$ untuk variabel kehandalan $\left(\mathrm{X}_{3}\right)$ sebesar 3,121 dan nilai $\mathrm{t}_{\text {tabel }}$ untuk $\mathrm{a}=0,05$ dengan derajat kebebasan (n-k1) $100-8-1=91$ sebesar 1,661 berarti $t_{3 h i t u n g}>$ $\mathrm{t}_{\text {tabel }}(3,121>1,661)$, maka Ho ditolak serta Ha diterima. Jadi, kehandalan berdampak positif dan nyata terhadap keputusan pembelian. Hal ini diketahui pada nilai koefisien regresi sebesar 0,479 serta memiliki nilai probabilitas $0,002<0,05$. Hasil penelitian yang diperoleh menemukan bahwa faktor kehandalan mempunyai kontribusi yang nyata pada keputusan pembelian.

\section{Pengaruh Kesesuaian $\left(\mathrm{X}_{4}\right)$ terhadap Keputusan Pembelian (Y)}

Berdasarkan hasil pengujian dapat diketahui bahwa nilai $t_{4 h i t u n g}$ untuk variabel kesesuaian $\left(\mathrm{X}_{4}\right)$ sebesar 1,990 dan nilai $t_{\text {tabel }}$ untuk $\mathrm{a}=0,05$ dengan derajat kebebasan (n-k1) $100-8-1=91$ sebesar 1,661 berarti $t_{4 h i t u n g}>$ $\mathrm{t}_{\text {tabel }}(1,990>1,661)$, maka Ho ditolak serta Ha diterima. Jadi, kesesuaian berpengaruh positif dan signifikan terhadap keputusan pembelian. Hal ini dapat diketahui pada nilai koefisien regresi sebesar 0,423 serta memiliki nilai probabilitas $0,050<0,05$. Hasil penelitian yang diperoleh menemukan bahwa faktor kesesuaian mempunyai kontribusi yang nyata pada keputusan pembelian.

\section{Pengaruh Daya Tahan (X) terhadap Keputusan Pembelian (Y)}

Berdasarkan hasil pengujian dapat diketahui bahwa nilai $t_{5 \text { hitung }}$ untuk variabel daya tahan $\left(\mathrm{X}_{5}\right)$ sebesar 1,460 dan nilai $t_{\text {tabel }}$ untuk $a=0,05$ dengan derajat kebebasan (n-k1) $100-8-1=91$ sebesar 1,661 berarti $t_{5 \text { hitung }}<$ $\mathrm{t}_{\text {tabel }}(1,460<1,661)$; maka Ha ditolak dan Ho diterima, artinya daya tahan tidak berdampak positif dan nyata terhadap keputusan pembelian. Hal ini dapat diketahui pada nilai koefisien regresi sebesar 0,251 serta memiliki nilai probabilitas $0,148>0,05$. Hasil penelitian yang diperoleh menemukan bahwa faktor daya tahan tidak memiliki pengaruh yang nyata terhadap keputusan pembelian.
Pengaruh Kemudahan Pelayanan $\left(\mathbf{X}_{6}\right)$ terhadap Keputusan Pembelian (Y)

Berdasarkan hasil pengujian dapat diketahui bahwa nilai $t_{6 h i t u n g}$ untuk variabel kemudahan pelayanan $\left(\mathrm{X}_{6}\right)$ sebesar 4,160 dan nilai $t_{\text {tabel }}$ untuk $a=0,05$ dengan derajat kebebasan (n-k-1) 100-8-1=91 sebesar 1,661 berarti $t_{6 h i t u n g}>t_{\text {tabel }}(4,160>1,661)$; maka Ho ditolak serta Ha diterima, artinya kemudahan pelayanan berdampak positif dan nyata terhadap keputusan pembelian.Hal ini dapat didiketahui pada nilai koefisien regresi sebesar 0,562 serta memiliki nilai probabilitas $0,000<0,05$. Hasil penelitian yang diperoleh menemukan bahwa faktor kemudahan pelayanan mempunyai kontribusi yang nyata terhadap keputusan pembelian.

\section{Pengaruh Estetika $\left(\mathbf{X}_{7}\right)$ terhadap Keputusan Pembelian (Y)}

Berdasarkan hasil pengujian dapat diketahui bahwa nilai ${ }_{7 \text { hitung }}$ untuk variabel estetika $\left(\mathrm{X}_{7}\right)$ sebesar 6,106 dan nilai $t_{\text {tabel }}$ untuk $\mathrm{a}=0,05$ dengan derajat kebebasan (n-k1) $100-8-1=91$ sebesar 1,661 berarti $t_{7 \mathrm{hitung}}>$ $\mathrm{t}_{\text {tabel }}(6,106>1,661)$; maka Ho ditolak serta Ha diterima. Jadi, estetika berpengaruh positif dan signifikan terhadap keputusan pembelian. Hal ini dapat diketahui pada nilai koefisien regresi sebesar 0,562 serta memiliki nilai probabilitas $0,000<0,05$. Hasil penelitian yang diperoleh menemukan bahwa faktor estetika mempunyai kontribusi yang nyata terhadap keputusan pembelian.

\section{Pengaruh Kesan Kualitas ( $\left.\mathbf{X}_{8}\right)$ terhadap Keputusan Pembelian (Y)}

Berdasarkan hasil pengujian dapat diketahui bahwa nilai tshitung untuk variabel kesan kualitas $\left(\mathrm{X}_{8}\right)$ sebesar1,504 dan nilai $\mathrm{t}_{\text {tabel }}$ untuk $\mathrm{a}=0,05$ dengan derajat kebebasan (n-k-1) $100-8-1=91$ sebesar 1,661 berarti $\mathrm{t}_{\text {shitung }}<\mathrm{t}_{\text {tabel }}(1,504<1,661)$; maka Ha ditolak serta Ho diterima. jadi, kesan kualitas tidak berpengaruh positif dan signifikan terhadap keputusan pembelian. Hal ini dapat diketahui pada nilai koefisien regresi sebesar 0,254 serta memiliki nilai probabilitas 0,136>0,05. Hasil penelitian yang diperoleh menemukan bahwa faktor kesan kualitas tidak mempunyai 
kontribusi yang nyata terhadap keputusan pembelian.

\section{SIMPULAN DAN SARAN}

\section{Simpulan}

Berdasarkan hasil dari penelitian yang telah diperoleh, maka bisa disimpulkan sebagai berikut:

1. Tanggapan konsumen sepeda motor matic Yamaha N-Max terhadap kualitas produk terdiri atas: kinerja berada pada kategori sangat baik, fitur berada pada kategori sangat baik, kehandalan berada pada kategori baik, kesesuaian berada pada kategori sangat baik, daya tahan berada pada kategori sangat baik, kemudahan pelayanan berada pada kategori sangat baik, estetika berada pada kategori baik, kesan kualitas berada pada kategori baik dan keputusan pembelian berada pada kategori baik.

2. Kualitas produk terdiri atas: kinerja, fitur, kehandalan, kesesuaian, daya tahan, kemudahan pelayanan, estetika dan kesan kualitas secara simultan berdampak positif dan nyata terhadap keputusan pembelian sepeda motor matic Yamaha N-Max di kota Bogor.

3. Kualitas produk yang terdiri atas: kinerja, fitur, kehandalan, kesesuaian, kemudahan pelayanan, dan estetika secara parsial berdampak positif dan nyata terhadap keputusan pembelian sepeda motor matic Yamaha N-Max di kota Bogor, sedangkan daya tahan dan kesan kualitas tidak berdampak positif dan nyata terhadap keputusan pembelian sepeda motor Yamaha N-Max di kota Bogor.

\section{Saran}

Berdasarkan hasil penelitian serta simpulan yang diperoleh, maka terdapat beberapa hal yang perlu dipertimbangkan. Penulis mengajukan saran-saran sebagai berikut:

1. Saran untuk variabel yang diteliti, di antaranya:

a. Kinerja pada indikator kemudahan pengoperasian, agar dapat memperhitungkan kembali dalam hal kendali dan memperhatikan aerodinamis sepeda motor, sehingga pada saat melaju dengan kecepatan tinggi sepeda motor dapat tetap stabil.

b. Fitur pada indikator ukuran bagasi, dapat ditingkatkan kembali dengan memperbesar kapasitas bagasi dan penambahan tutup yang terpisah dengan jok motor.

c. Kehandalan pada indikator handal disegala medan jalan, dapat diperhatikan kembali dalam hal pemilihan suspensi dan ground clerence. Suspensi yang keras dapat mengurangi kenyamanan dalam berkendara, serta rendahnya jarak tinggi motor ke muka jalan menyebabkan komponen yang berada pada bagian bawah motor dapat cepat mengalami kerusakkan.

d. Kesesuain pada indikator kesesuian desain, agar dapat ditingkatkan kembali melalui penambahan visor pada bagian depan motor, yang dimaksudkan untuk menghadang angin kearah pengendara. Serta meningkatkan kualitas material pada bagian body motor agar lebih kokoh dan tangguh.

e. Daya tahan pada indikator masa pakai, dapat ditingkatkan kembali dalam hal ketahanan mesin dan juga suku cadang dengan cara melakukan pengujian daya tahan mesin, sehingga Yamaha dapat mengetahui batas kemampuan mesin, denganin formasi yang diperoleh, perusahaan dapat melakukan perbaikan dan meningkatkan daya tahan mesin.

f. Kemudahan pelayanan pada indikator pelayanan memuaskan agar dapat ditingkatkan kembali melalui peningkatan pelayanan konsumen baik dalam hal penjualan sepeda motor dengan memberikan service gratis maupun saat melakukan perbaikan di dealer-dealer. Serta dapat memastikan suku cadang dan aksesoris motor tetap tersedia agar memenuhi permintaan konsumen, 
sehingga konsumen tidak perlu menunggu lama untuk mendapatkan suku cadang atau aksesoris motor yang diperlukannya.

g. Estetika pada indikator suara mesin agar dapat diperhatikan kembali bahwa suara mesin yang kasar dapat mengganggu kenyamanan dalam berkendara. Hal ini dapat diatasi dengan penggunaan knalpot yang telah dilengkapi peredam suara (cattalyst) agar suara mesin tidak terlalu bising.

h. Kesan kualitas pada indikator tanggung jawab perusahaan agar meningkatkan interaksi dengan konsumen baik melalui media sosial ataupun media lainnya, agar tercipta kesan kualitas yang lebih baik.

2. Untuk Peneliti selanjutnya semoga ini menjadi manfaat dan referensi untuk melakukan penelitian mengenai kualitas produk, serta dapat dikembangkan dengan menambahkan variabel lain yang mempengaruhi keputusan pembelian, diantaranya budaya, sosial, kepribadian, psikologis.

\section{UCAPAN TERIMA KASIH}

Ucapan terima kasih kepada Komunitas Motor Yamaha N-Max di Kota Bogor, yaitu YNCI (Yamaha N-Max Club Indonesia), Max Republic, Bogor Max Owner, dan NMax Rider Bogor.

\section{DAFTAR PUSTAKA}

Alma, Buchari. 2012. Manajemen Pemasaran dan Pemasaran Jasa. Bandung: Alfabeta.

Amrullah. 2016. "Pengaruh Kualitas Produk dan Kualitas Layanan terhadap Keputusan Pembelian Sepeda Motor Honda", Jurnal Ekonomi dan Manajemen, Vol 13, No 2, ISSN 25281127, Hal 116 (Sumber: http://journal.feb.unmul.ac.id diakses pada tanggal 30 Oktober2019 pukul 10:35).
Boyd, dkk. 2000. Manajemen Pemasaran. Edisi kedua Jilid 1. Alih Bahasa: Imam Nurmawan: Yati Sumiharti, S.E. Jakarta: Erlangga.

Durianto, Darmadi, Sugiarto, dan Tony Sitinjak. 2001. Strategi Menaklukkan Pasar Melalui Riset Ekuitas dan Perilaku Merek, Jakarta.

Heizer, Jay dan Barry Render. 2012. Manajemen Operasi. Edisi 9. Jakarta; Salemba Empat.

Kotler, Philip dan Garry Armstong. 2012. Prinsip-prinsip Pemasaran. Edisi 13 Jilid 1, Erlangga, Jakarta.

Kotler, Philip dan Kevin Lane Keller. 2012. Marketing Management Edition. New Jersey: Pearson Education, Inc.

Kristian, Denny dan Rita Widayanti. 2016. "Pengaruh Kualitas Produk Dan Harga Terhadap Keputusan Pembelian Sepeda Motor Honda Pada Mahasiswa kampus 1 Universitas Kristen Krida Wacana", Jurnal Ilmiah Manajemen Bisnis, Vol 16, No 1, ISSN 2451-67X, Hal 57 (Sumber: http://ejournal.ukrida.ac.id/ diakses pada tanggal 30 Oktober 2019 pukul 17:23).

Kurniawati, Silvia Widyastuti. 2013. "Pengaruh Kualitas Produk Terhadap Keputusan Pembelian Suzuki Nexdi Surabaya Selatan" JurnalManajemen dan Kewirausahaan, Vol. 12, No. 2, ISSN 2456-0045 (Sumber: https://journal.managementandentrepren er.ac.id diakses pada tanggal 29 Mei 2019 pukul 16:21).

Mowen, John C; Michael Minor. 2008. Consumer Behavior 6ed. New Jersey: Prentice-Hall, Inc.

Munawaroh, Siti. 2011. "Pengaruh Kualitas Produk, Promosi dan Desain terhadap Keputusan PembelianKendaraan Bermotor Yamaha Mio di Banjarbaru Kalimantan Selatan", Jurnal Pemasaran Kompetitif, Vol 12, No 2, ISSN 25980822, Hal 64-76 (Sumber: https://journalpemasaran.stiei.ac.id diakses pada tanggal 02 Januari 2018 pukul 13:06). 
Putra, Giardo Permadi. 2017. "Pengaruh Kualitas Produk terhadap Keputusan Pembelian dan Dampaknya terhadap Kepuasan Konsumen", Jurnal Administrasi Bisnis, Vol 48, No 1, ISSN 2241-68X, Hal 125-131 (Sumber: https://administrasibisnis.studentjournal. ub.ac.id diakses pada tanggal 01 Januari 2018 pukul 14:25).

Santoso, Heru dan Yoyok Soesatyo. 2014. "Pengaruh Kualitas Produk dan Harga TerhadapMinat Beli Nokia Lumia 520 Di Surabaya", Jurnal IlmuManajemen, Vol 2, No 2, ISSN 2518-1227, Hal 569570(https://jurnalmahasiswa.unesa.ac.id I_diakses pada tanggal 30 Oktober 2019 pukul 10:42).

Sinambela, Sarton. 2010. "Pengaruh Merek dan Dimensi Kualitas Pada Produk Sepatu Olah Raga Nike Terhadap Keputusan Pembelian", Jurnal Manajemen dan Akuntansi, Vol 6, No 1, ISSN 0216-5112, Hal 32 (Sumber: http://portal.kopertis3.or.id/ diakses pada tanggal 30 Oktober 2019 pukul $14: 45)$.
Sugiyono. 2014. Metode Penelitian Kuantitatif Kualitatif dan R\&D, Alfabeta, Bandung.

Thomson. 2012. “Analisis Pengaruh Kualitas Pelayanan Konsumen Pada Warung Ucok Durian Iskandar Muda Medan Terhadap Keputusan Pembelian", Jurnal Ilmu Manajemen, Vol 1, No 1, ISSN 2721-67X, Hal 9 (Sumber: https://jurnal.usu.ac.id/ diakses pada tanggal 30 Oktober 2019 pukul 14:30).

Tjiptono, Fandy. 2015. Strategi Pemasaran, Edisi 4, Penerbit Andi, Yogyakarta. . 2009. Service Marketing: Esensi \& Aplikasi. Penerbit: Marknesis. Yogyakarta.

Umar, Husein. 2003. Metode Riset Perilaku Organisasi. Jakarta: PT. Gramedia Pustaka Utama.

Sumber lain dari website :

http://www.bps.go.id (diakses pada 12 Januari 2018 pukul 10.02)

https://www.aisi.or.id (diakses pada 12 Juli 2018 pukul 11.32 WIB) 